\title{
Immunohistochemical assay for neuron-specific enolase, synaptophysin, and RB-associated protein as a diagnostic aid in advanced retinoblastomas
}

This article was published in the following Dove Press journal: Clinical Ophthalmology

\author{
José Carlos López López' \\ Nieves Fernández Alonso' \\ Juan Cuevas Álvarez ${ }^{1,2}$ \\ Tomás García-Caballero² \\ José Carlos Pastor Jimeno 3 \\ 'Ocular Pathology Laboratory, \\ Instituto Universitario de \\ Oftalmobiología Aplicada (IOBA), \\ University of Valladolid, Valladolid, \\ Spain; '2Department of Pathology, \\ Hospital Clínico Universitario, \\ Santiago de Compostela, Spain; \\ ${ }^{3}$ Retina Group, Instituto Universitario \\ de Oftalmobiología Aplicada (IOBA), \\ University of Valladolid, Hospital \\ Clínico Universitario, Valladolid, Spain
}

Correspondence: José Carlos López López

Laboratorio de Anatomía Patológica Ocular, Instituto Universitario de Oftalmobiología Aplicada (IOBA), University of Valladolid, Campus Miguel Delibes, Paseo de Belén, 17, 470II

Valladolid, Spain

Tel +34983 I84764

Fax +34983 184762

Email jclopezl@ioba.med.uva.es
Purpose: We evaluated the expression of the neural markers, neuron-specific enolase, and synaptophysin, as a tool to confirm the diagnosis of retinoblastoma (RB) in undifferentiated and advanced tumors. Additionally, we determined whether the extent of RB-associated protein $(\mathrm{pRb})$ expression is helpful in assessing the prognosis in $\mathrm{RB}$ patients.

Methods: Conventional whole tissue section and tissue microarray immunohistochemistry for neuron-specific enolase, synaptophysin, and $\mathrm{pRb}$ were carried out in a series of $22 \mathrm{RBs}$.

Results: Neuron-specific enolase and synaptophysin were expressed in $75 \%-100 \%$ of the tumor cells, and the staining intensity was strong. Two RBs expressed $\mathrm{pRb}$ in $75 \%-100 \%$ of the tumor cells, also with strong staining intensity. Concordance between the immunohistochemical outcomes for whole tissue staining and tissue microarray staining was $76.2 \%$ for neuron-specific enolase, $85.7 \%$ for synaptophysin, and $80.0 \%$ for $\mathrm{pRb}$.

Conclusion: Neuron-specific enolase and synaptophysin have the potential to be useful markers for the diagnosis of RBs. Extensive and strong pRb staining is not associated with less aggressive tumor behavior according to the pathologic classification of RBs.

Keywords: retinoblastoma, immunohistochemistry, neuron-specific enolase, synaptophysin, pRb

\section{Introduction}

Retinoblastoma $(\mathrm{RB})$ is the most common primary intraocular malignant tumor in children. ${ }^{1}$ The incidence ranges from $1: 14,000$ to $1: 20,000$ live births $(7,000-8,000$ new cases per year worldwide). Incidence rates in the USA are 2.9 cases per 100,000 per year in children younger than 1 year and 1.6 cases per 100,000 per year in 1 -yearold children. More than $90 \%$ of these cases are diagnosed before the age of 5 years. The frequency is higher in Africa, India, and Latin America.

The current survival rate in the USA approaches 100\%. However, in Africa, this rate is very low between $20 \%$ and $46 \% .^{2}$ If survival rates were similar to the developed countries globally, RB deaths could be reduced by $88 \%$. RB metastases occur in less than $5 \%$ of patients in developed countries but still represent a challenge in developing countries. ${ }^{3}$

The RB gene $(R B 1)$ is localized to chromosome 13q14.2. This is the first tumor suppressor gene described and was isolated in $1986 .{ }^{4} \mathrm{RB}$ develops when biallelic inactivation or loss of both alleles occur. This is consistent with Knudson's "two-hit" hypothesis in which two complementary events are necessary to convert a normal retinal cell into a tumor cell..$^{5}$ In $60 \%$ of cases, mutations appear locally in the developing retina. About $40 \%$ have germline mutations of the $R B 1$ gene and are inherited 
in an autosomal dominant fashion. All bilateral cases are the result of germline mutations. ${ }^{6}$

The $R B 1$ gene encodes a protein, RB-associated protein $(\mathrm{pRb})$, that acts as a tumor growth suppressor. ${ }^{7,8} \mathrm{pRb}$ is a 928 amino acid nuclear phosphoprotein that plays a critical role in regulating cell cycle progression at the $\mathrm{G} 1 / \mathrm{S}$ phase transition. During the G0/G1 phase, the hypophosphorylated active form interacts with the E2F family of transcription factors, inhibiting the transcription of E2F target genes. In response to mitogenic stimuli, $\mathrm{pRb}$ is phosphorylated and E2F transcription factors are released, inducing gene expression leading to progression through the cell cycle.

The histogenesis of RB is not well known. Recent findings indicate that RB cells derive from cone precursors. ${ }^{9}$ Histological examination reveals that RB cells are undifferentiated, having scant cytoplasm and prominent, oval or round basophilic nuclei with finely granular chromatin and no nucleoli. Numerous mitotic figures are usually found. Formation of Flexner-Wintersteiner rosettes is a characteristic of RBs. These rosettes are composed of a ring of high cuboidal cells surrounding an apical lumen. ${ }^{10-13}$ Tumor growth rate is limited by the ability to induce the formation of new vessels; hence, large areas of coagulative necrosis and dystrophic calcification frequently appear. ${ }^{14}$

Immunohistochemistry is widely used in histopathologic diagnosis and for research purposes. ${ }^{15,16}$ However, no specific marker is currently available for RB. The use of neuron-specific enolase and synaptophysin could improve the diagnostic accuracy in RB, which would be very useful in advanced tumors.

The practice of transferring multiple tissue samples to a single slide for immunohistochemical analysis was implemented by Battifora in $1986 .{ }^{17}$ In 1998 , Kononen et al ${ }^{18}$ invented a mechanism that allowed the quick and precise construction of tissue microarrays that greatly facilitated analysis. It enabled the standardization of immunohistochemical studies because all specimens are processed at one time under identical conditions. The main drawback of tissue microarray analysis is the partial or total loss of one or more tissue core samples. Because $\sim 10 \%-15 \%$ of the tissue cores can be lost, ${ }^{19}$ the inclusion of two cores per tumor is usually sufficient and comparable to the study of whole tissue sections in more than $95 \%$ of cases. ${ }^{20}$

Undifferentiated and advanced RB tumors, especially those masses with extensive necrosis where no ocular structures are identifiable, can pose a diagnostic challenge to pathologists. Therefore, the purpose of this study was to test the value of assessing the expression of neuron-specific enolase and synaptophysin, both of which are neural markers, as a tool to confirm the diagnosis of undifferentiated and advanced RB tumors in Angolan patients.

\section{Patients and methods Tissue samples}

This study was performed in accordance with tenets of the Declaration of Helsinki, and all procedures were approved by the University of Valladolid ethics committee. Informed written consent was obtained from the parents of each of the patients.

Retinoblastoma patients ( $n=21 ; 11$ males and 10 females) were selected from the archives of IOBA Ocular Pathology Laboratory covering a 10 -year period. In one RB patient, after the right eye was removed, metastatic masses were subsequently found in the right lower eyelid and cheek. Thus, tissue samples from 22 RB tumors (17 eye enucleations and 5 eviscerations) were analyzed by standard light microscopy and by immunohistochemistry of formalin-fixed and paraffin-embedded tissue blocks. Twenty-one patients were from Angola as arranged by an agreement between the University of Valladolid and the National Eye Institute of Angola. All eye specimens obtained from Angolan patients were sent to Spain for processing and diagnosis. Enucleation and evisceration specimens were fixed in 10\% formalin and sent by express mail to Spain. The specimens arrived 7-10 days after surgery. One case from a Spanish patient showing superficial invasion of the optic nerve was also included.

American Joint Committee on Cancer, Cancer Staging Manual guidelines for pathological staging were used.

The samples were processed in a Leica ASP-300 tissue processor (Leica Biosystems, Nussloch, Germany) using a 32-hour program for eye globes. The globes were subsequently embedded in paraffin, and 4- $\mu \mathrm{m}$ sections were obtained and collected on FLEX IHC Microscope Slides (Dako, Glostrup, Denmark).

The degree of necrosis in H\&E sections was evaluated as focal $(<25 \%)$, moderate $(\geq 25 \%-50 \%)$, extensive $(>50 \%-75 \%)$, or very extensive $(>75 \%)$ of the tumor cells. The degree of apoptosis in H\&E sections was evaluated as focal $(<10 \%)$, moderate $(\geq 10 \%-25 \%)$, or intense $(>25 \%)$ of tumor cells.

A manual tissue microarray instrument (Beecher Instruments, Silver Spring, MD, USA) was used to construct each microarray. The most appropriate tumor areas were identified on H\&E-stained sections from each tissue donor block. Two cores of $1.5-\mathrm{mm}$ diameter were taken per case. A total of 44 cores were present in the tissue microarray block. 


\section{Immunohistochemistry}

The immunohistochemical study was performed in a Dako Autostainer Link 48 instrument (Dako) for both whole tissue sections and tissue microarrays.

\section{Pretreatment}

Heat-induced epitope retrieval was performed in a Dako PT Link (Dako) using EnVision ${ }^{\mathrm{TM}}$ FLEX Target Retrieval Solution, High pH (50×) (Dako) for neuron-specific enolase and synaptophysin. EnVision ${ }^{\mathrm{TM}}$ FLEX Target Retrieval Solution, Low $\mathrm{pH}(50 \times)$ (Dako) was used for $\mathrm{pRb}$. The slides were washed in Envision ${ }^{\mathrm{TM}}$ Flex Wash Buffer 20× (Dako) at room temperature (RT) for 5 minutes. Inhibition of endogenous peroxidases was achieved using EnVision ${ }^{\mathrm{TM}}$ FLEX Peroxidase-Blocking Reagent (Dako) for $5 \mathrm{~min}$.

\section{Incubation with primary antibodies}

Ready-to-use primary monoclonal antibodies were employed for neuron-specific enolase and synaptophysin. $\mathrm{pRb}$ antibody was used at a 1:25 dilution (Table 1). Negative control slides were incubated with ready-to-use FLEX Negative Control Mouse (Dako). The slides were treated with EnVision $^{\text {TM }}$ FLEX/HRP for 20 min, followed by washing with EnVision $^{\text {TM }}$ FLEX Wash Buffer (20×). Substrate + chromogen (diaminobenzidine) were then applied, followed by another washing with EnVision ${ }^{\mathrm{TM}}$ FLEX Wash Buffer $(20 \times)$. The tissue was then counterstained with EnVision ${ }^{\mathrm{TM}}$ FLEX Hematoxylin.

\section{Assessment of immunohistochemical staining}

A semiquantitative assessment of the immunohistochemical results was carried out by one of the authors according to the scheme used by The Swedish Human Protein Atlas Project. ${ }^{21}$ All samples were examined under the microscope at low and high magnifications. The fraction of stained cells was scored as $<25 \%, \geq 25 \%-75 \%$, or $>75 \%$. The staining intensity was scored as negative, weak, moderate, or strong. The subcellular localization was designated as nuclear, cytoplasmic, or membranous.

In the tissue microarray, two cores were used from each case to avoid tissue lost. Study cases were excluded only if both cylinders were lost. This occurred for one case each stained for neuron-specific enolase and synaptophysin, and for two cases of $\mathrm{pRb}$. A map specifying the exact position of each tumor was prepared to facilitate the interpretation of the results. When the scores differed between two cores of the same case, the highest score was used.

The percentage of immunohistochemical staining outcomes that were concordant between the whole tissue sections and the core tissue sections was calculated as follows:

\section{$\frac{\text { Concordant cases }}{\text { Concordant cases }+ \text { discordant cases }} \times 100$}

\section{Results}

In 13 cases (59\%), the tumor was in the left eye, and in nine cases (41\%), it was in the right eye. The median age at diagnosis was 2.9 years (range $1-8$ years). The degree of necrosis was extensive in 13 tumors and very extensive in three of the tumors. The degree of apoptosis was moderate or intense in most of the tumors studied (19 cases). Calcifications were present in 18 of the RBs. The median number of mitotic cells per 10 high power fields (40×) was 12.76 . Choroidal and scleral invasion were present in 17 tumors. The diameter of uveal invasion was greater than $3 \mathrm{~mm}$ in most of the cases. In many, malignant cells affected the internal fibers of the sclera; therefore, these infiltrations were classified as significant choroidal invasion according to the recommendations of the International Retinoblastoma Staging Working Group. ${ }^{22}$ Anterior chamber invasion was

Table I Primary antibodies and incubation protocols

\begin{tabular}{|c|c|c|c|c|c|}
\hline Antibody ${ }^{a}$ & Clone & Product code & Source & Dilution & Time/temp \\
\hline $\begin{array}{l}\text { Monoclonal mouse anti- } \\
\text { human neuron-specific } \\
\text { enolase }\end{array}$ & BBS/NC/VI-HI4 & M0873 & Dako, Glostrup, Denmark & NA & $30 \mathrm{~min} / \mathrm{RT}$ \\
\hline $\begin{array}{l}\text { Monoclonal mouse anti- } \\
\text { human synaptophysin }\end{array}$ & DAK-SYNAP & M73I5 & Dako, Glostrup, Denmark & NA & $20 \mathrm{~min} / \mathrm{RT}$ \\
\hline $\begin{array}{l}\text { Novocastra }{ }^{\mathrm{TM}} \text { liquid mouse } \\
\text { monoclonal antibody } \\
\text { retinoblastoma gene protein }\end{array}$ & I3A 10 & NCL-L-RB-358 & $\begin{array}{l}\text { Leica Biosystems Newcastle } \\
\text { Ltd., Newcastle Upon } \\
\text { Tyne, UK }\end{array}$ & $\begin{array}{l}\text { I:25 with EnVision }{ }^{\mathrm{TM}} \text { FLEX } \\
\text { Antibody Diluent (Dako, } \\
\text { Glostrup, Denmark) }\end{array}$ & $60 \mathrm{~min} / \mathrm{RT}$ \\
\hline
\end{tabular}

Note: ${ }^{a} A l l$ isotypes were $\lg G I$.

Abbreviations: IgGI, immunogloublin GI; NA, not applicable; RT, room temperature. 
identified in 18 cases. Sixteen cases $(72.7 \%)$ were classified as pT4 tumors, which are characterized by tumor invasion of the optic nerve to the resection line or exhibited extraocular extension elsewhere. ${ }^{23}$

\section{Immunohistochemistry Whole tissue sections}

For neuron-specific enolase, 17 RBs (77\%) had 75\%-100\% positive cells and five cases (23\%) had 25\%-75\% positive cells. Twenty RBs (91\%) were strongly positive (Figure 1A) and two cases $(9 \%)$ were moderately positive. Necrotic cells in all cases were strongly positive.

For synaptophysin, 20 tumors (91\%) had 75\%-100\% positive cells (Figure 1B) and two (9\%) had 25\%-75\% positive cells. All 22 tumors were strongly positive. Greater staining intensity for synaptophysin was localized to apical cytoplasm of Flexner-Wintersteiner rosettes (Figure 1C). In all cases, necrotic cells were strongly positive.

For $\mathrm{pRb}$, one case was positive in more than $75 \%$ of the tumor cells and had moderate expression in the nucleus (Figure 1D). Twenty-one tumors (95.5\%) were negative for $\mathrm{pRb}$ (Tables 2 and 3).

\section{Tissue microarrays}

For neuron-specific enolase, in 14 tumors (67\%), 75\%-100\% of the cells were positive and had strong staining intensity
(Figure 2A). Six tumors (28\%) had 25\%-75\% positive cells that were stained with moderate intensity. One tumor $(5 \%)$ was focally positive with less than $25 \%$ of the cells stained. Both cylinders were lost in one case, which was excluded for evaluation. There was $76.2 \%$ concordance with the results obtained from conventional whole tissue sections (Table 4).

For synaptophysin, in 18 tumors (86\%), 75\%-100\% of the cells were positive and had strong staining intensity (Figure 2B). Two cases (9\%) had 25\%-75\% positive cells with moderate staining intensity, and one case (5\%) had focal staining with less than $25 \%$ positive cells. Both cylinders were lost in one case so it could not be used for evaluation. There was $85.7 \%$ concordance with the results obtained from whole tissue sections (Table 5).

For $\mathrm{pRb}$, in two cases $(10 \%), 75 \%-100 \%$ of the cells were positive and had strong staining intensity (Figure 2C). Three cases $(15 \%)$ had focal staining with less than $25 \%$ positive cells, and 15 tumors (75\%) were completely negative for pRb. In two cases, both cylinders were lost so only 20 RBs could be used for evaluation. There was $80.0 \%$ concordance with the results obtained from conventional whole tissue sections (Table 6).

\section{Discussion}

In developed countries, RBs are usually diagnosed at early stages, when tumors are small and confined to the eye. Eyeconservative therapy is the standard treatment in these cases;
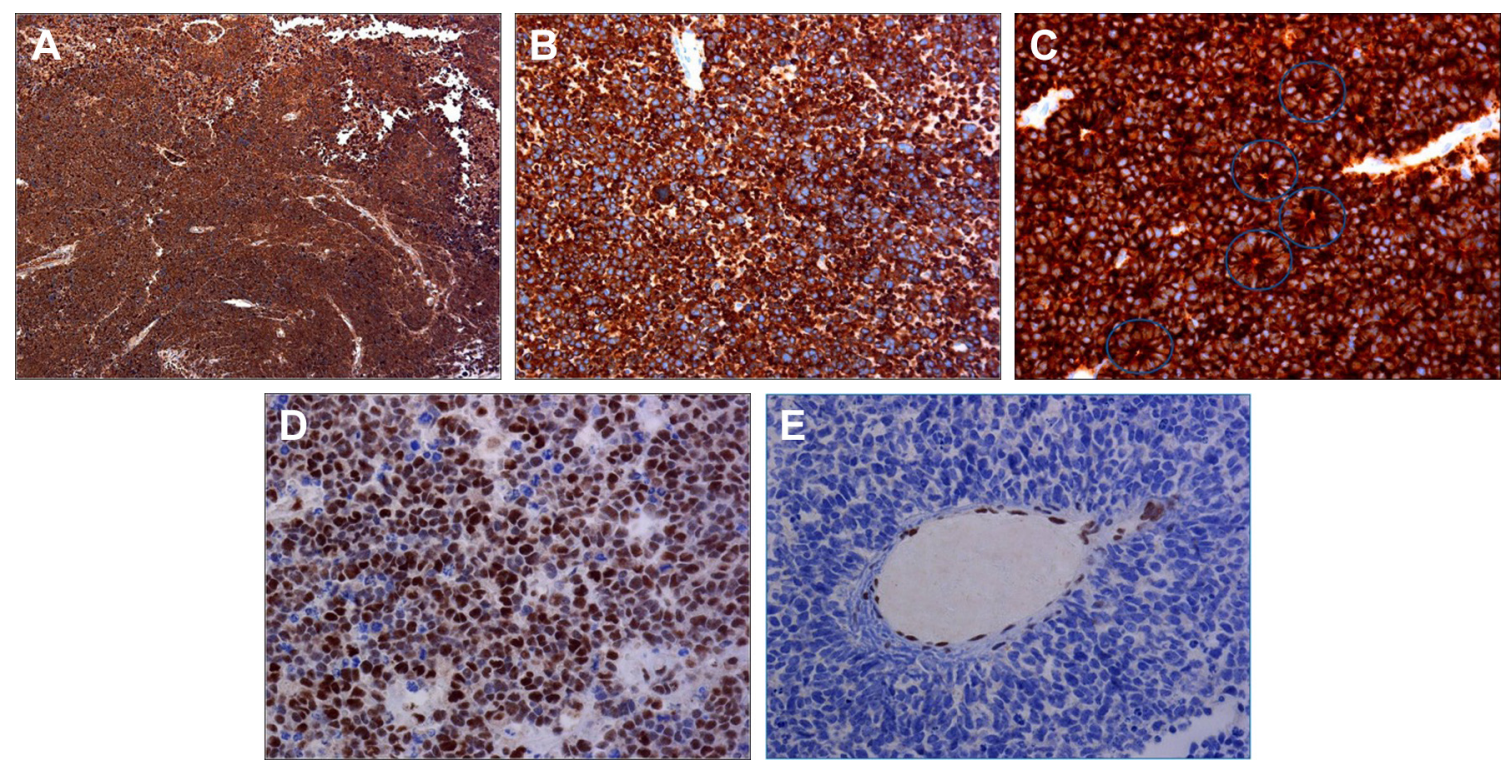

Figure I Whole tissue section immunohistochemistry.

Notes: (A) Neuron-specific enolase. In this case, there was widespread and intense staining for neuron-specific enolase. I0x. (B) Synaptophysin. This RB sample also had widespread and intense staining for synaptophysin. 20×. (C) Synaptophysin distribution in Flexner-Wintersteiner rosettes. This RB had greater staining intensity for synaptophysin located in the apical cytoplasm of Flexner-Wintersteiner rosettes. 40×. (D) pRb. This was diffusely present in the nuclei of RB cells. 40X. (E) RB negative for pRb. The tumor cells in this RB did not express pRb; however, the vascular endothelial cells, which served as an internal immunohistochemical control, did express it. 40×. Abbreviations: pRb, RB-associated protein; RB, retinoblastoma. 
Table 2 Immunohistochemistry: whole tissue sections

\begin{tabular}{llll}
\hline $\begin{array}{l}\text { Case } \\
\text { number }\end{array}$ & $\begin{array}{l}\text { Neuron- } \\
\text { specific enolase }\end{array}$ & Synaptophysin & pRb \\
\hline 1 & $75 \%-100 \%$ & $75 \%-100 \%$ & Negative \\
2 & $75 \%-100 \%$ & $25 \%-75 \%$ & Negative \\
3 & $25 \%-75 \%$ & $75 \%-100 \%$ & Negative \\
4 & $75 \%-100 \%$ & $75 \%-100 \%$ & Negative \\
5 & $75 \%-100 \%$ & $75 \%-100 \%$ & Negative \\
6 & $25 \%-75 \%$ & $25 \%-75 \%$ & Negative \\
7 & $75 \%-100 \%$ & $75 \%-100 \%$ & Negative \\
8 & $75 \%-100 \%$ & $75 \%-100 \%$ & Negative \\
9 & $75 \%-100 \%$ & $75 \%-100 \%$ & Negative \\
10 & $75 \%-100 \%$ & $75 \%-100 \%$ & Negative \\
11 & $75 \%-100 \%$ & $75 \%-100 \%$ & Negative \\
12 & $75 \%-100 \%$ & $75 \%-100 \%$ & Negative \\
13 & $75 \%-100 \%$ & $75 \%-100 \%$ & Negative \\
14 & $75 \%-100 \%$ & $75 \%-100 \%$ & Negative \\
15 & $25 \%-75 \%$ & $75 \%-100 \%$ & Negative \\
16 & $75 \%-100 \%$ & $75 \%-100 \%$ & Negative \\
17 & $75 \%-100 \%$ & $75 \%-100 \%$ & Negative \\
18 & $25 \%-75 \%$ & $75 \%-100 \%$ & Negative \\
19 & $25 \%-75 \%$ & $75 \%-100 \%$ & Negative \\
20 & $75 \%-100 \%$ & $75 \%-100 \%$ & Negative \\
21 & $75 \%-100 \%$ & $75 \%-100 \%$ & $75 \%-100 \%$ \\
22 & $75 \%-100 \%$ & $75 \%-100 \%$ & Negative \\
\hline
\end{tabular}

Note: Fraction of stained cells expressed in percentage of positive cells. Abbreviation: $\mathrm{pRb}$, retinoblastoma-associated protein.

hence, the proportion of patients treated with enucleation is decreasing in high-income countries. ${ }^{2}$ However, enucleation is required for more advanced tumors, and all enucleated eye globes must be submitted for a complete histopathological examination by an experienced ocular pathologist.

Table 3 Immunohistochemistry: whole tissue sections

\begin{tabular}{llll}
\hline $\begin{array}{l}\text { Case } \\
\text { number }\end{array}$ & $\begin{array}{l}\text { Neuron-specific } \\
\text { enolase }\end{array}$ & Synaptophysin & pRb \\
\hline 1 & Strong & Strong & Negative \\
2 & Strong & Strong & Negative \\
3 & Strong & Strong & Negative \\
4 & Strong & Strong & Negative \\
5 & Strong & Strong & Negative \\
6 & Strong & Strong & Negative \\
7 & Strong & Strong & Negative \\
8 & Strong & Strong & Negative \\
9 & Strong & Strong & Negative \\
10 & Strong & Strong & Negative \\
11 & Strong & Strong & Negative \\
12 & Strong & Strong & Negative \\
13 & Strong & Strong & Negative \\
14 & Strong & Strong & Negative \\
15 & Strong & Strong & Negative \\
16 & Strong & Strong & Negative \\
17 & Strong & Strong & Negative \\
18 & Moderate & Strong & Negative \\
19 & Moderate & Strong & Negative \\
20 & Strong & Strong & Negative \\
21 & Strong & Strong & Moderate \\
22 & Strong & Strong & Negative \\
\hline
\end{tabular}

Note: Intensity of stained cells.

Abbreviation: $\mathrm{pRb}$, retinoblastoma-associated protein.
The grade of optic nerve involvement and the age at diagnosis of infiltration are the factors most significantly associated with survival in RB patients. ${ }^{24}$ If tumor cells infiltrate the optic nerve beyond the lamina cribrosa and there is also involvement of the surgical margin, the mortality rate rises to $78 \%$.

Invasion of the optic nerve beyond the lamina cribrosa, choroidal invasion, scleral invasion, and infiltration of the anterior segment are considered high-risk histopathologic factors. The presence of these high-risk factors is associated with an increased risk of local recurrence and metastases. ${ }^{22,25}$ Advanced tumors are often found in developing countries like Angola, and the diagnosis is made when extraocular invasion has already occurred. Conditions to be considered in the differential diagnosis of RBs include rhabdomyosarcoma, Burkitt's lymphoma, primitive neuroectodermal tumor, and orbital metastases of a Wilms' tumor.

Based on the histopathological findings, patients can be divided into three categories: low, medium, and high risk. ${ }^{26}$ Those who fall into the medium- and high-risk categories receive chemotherapy. More aggressive treatment is given to the high-risk group. Sadly, in many cases, children living in developing countries may not have access to these therapies. Another issue is poor access to a complete histopathology report. ${ }^{27}$

The presence of optic nerve infiltration of all the RBs in this study and the existence of choroidal, scleral, and anterior chamber invasion in most of the tumors are likely to be related to the delay in the diagnosis of Angolan patients. Unfortunately, when the diagnosis is delayed, RBs grow in an uncontrolled manner.

In 1984, Kyritsis et al used immunofluorescence microscopy to search for neuron-specific enolase and glial fibrillary acidic protein in Y-79 cells, a human RB cell line. ${ }^{28}$ They found that undifferentiated cells expressed both markers while those differentiated to neurons expressed only neuronspecific enolase. Y-79 cells that differentiated to glial cells expressed glial fibrillary acidic protein. This differential expression was related to a change in cell morphology, and they suggested that RBs originate from primitive neuroectodermal cells with the ability to differentiate to neural or glial cell lines. ${ }^{28}$

In the late 1980 s and in the 1990 s, the first immunohistochemical studies were performed on RB surgical specimens to identify the cell of origin. Antibodies against target proteins included the neuronal markers synaptophysin and neuron-specific enolase, glial markers S-100 and glial fibrillary acidic protein, and other markers including $\mathrm{pRb}$, $\mathrm{p} 53$, and bcl-2. ${ }^{29-32}$ In the late $1990 \mathrm{~s}$, these efforts were 

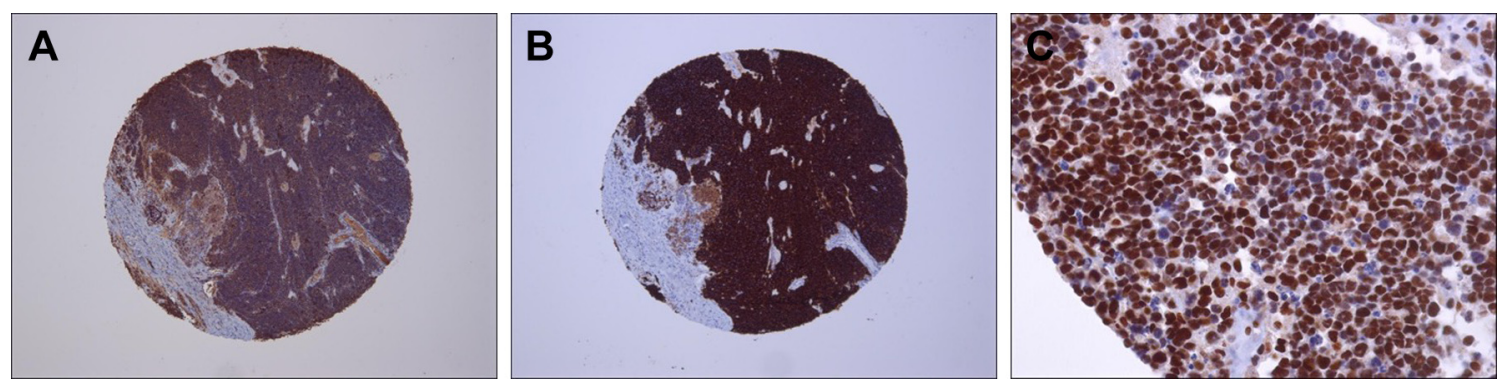

Figure 2 Tissue microarray immunohistochemistry.

Notes: (A) Neuron-specific enolase. This case shows widespread and intense staining for neuron-specific enolase. $5 \times$. (B) Synaptophysin. All tumor cells present in the core were intensely positive for synaptophysin. $5 \times$. (C) pRb. All of the nuclei were positive for pRb. $40 \times$.

Abbreviation: $\mathrm{pRb}$, retinoblastoma-associated protein.

abandoned, probably because it was assumed that the RB cell of origin was the one that expressed neural markers or neural and glial markers. In the present study, we sought a new approach to test the value of neuron-specific enolase and synaptophysin (neural markers) expression as a tool to confirm the diagnosis of RBs. Also, the degree of $\mathrm{pRb}$ expression would help to assess the prognosis in RB patients as shown in other tumors. ${ }^{33}$

Molnar et al reported the immunohistochemical distribution of neuron-specific enolase, glial fibrillary acidic protein, myelin-associated glycoprotein, and S-100 on

Table 4 Immunohistochemistry: neuron-specific enolase: whole tissue sections and tissue microarray

\begin{tabular}{lll}
\hline $\begin{array}{l}\text { Neuron-specific } \\
\text { enolase }\end{array}$ & $\begin{array}{l}\text { Whole tissue } \\
\text { sections }\end{array}$ & $\begin{array}{l}\text { Tissue } \\
\text { microarray }\end{array}$ \\
\cline { 1 - 3 } Case number & & $75 \%-100 \%$ \\
\hline 1 & $75 \%-100 \%$ & $25 \%-75 \%$ \\
2 & $75 \%-100 \%$ & $<25 \%$ \\
3 & $25 \%-75 \%$ & $75 \%-100 \%$ \\
4 & $75 \%-100 \%$ & $75 \%-100 \%$ \\
5 & $75 \%-100 \%$ & Missing cores \\
6 & $25 \%-75 \%$ & $75 \%-100 \%$ \\
7 & $75 \%-100 \%$ & $75 \%-100 \%$ \\
8 & $75 \%-100 \%$ & $75 \%-100 \%$ \\
9 & $75 \%-100 \%$ & $75 \%-100 \%$ \\
10 & $75 \%-100 \%$ & $75 \%-100 \%$ \\
11 & $75 \%-100 \%$ & $25 \%-75 \%$ \\
12 & $75 \%-100 \%$ & $75 \%-100 \%$ \\
13 & $75 \%-100 \%$ & $25 \%-75 \%$ \\
14 & $75 \%-100 \%$ & $25 \%-75 \%$ \\
15 & $25 \%-75 \%$ & $25 \%-75 \%$ \\
16 & $75 \%-100 \%$ & $75 \%-100 \%$ \\
17 & $75 \%-100 \%$ & $75 \%-100 \%$ \\
18 & $25 \%-75 \%$ & $25 \%-75 \%$ \\
19 & $25 \%-75 \%$ & $75 \%-100 \%$ \\
20 & $75 \%-100 \%$ & $75 \%-100 \%$ \\
21 & $75 \%-100 \%$ & $75 \%-100 \%$ \\
22 & $75 \%-100 \%$ & \\
\hline$N$ & &
\end{tabular}

Note: Fraction of stained cells expressed in percentage of positive cells. seven human RBs. ${ }^{34}$ In that study, most of the tumor cells were positive for neuron-specific enolase, but FlexnerWintersteiner rosettes were negative or weakly positive. In our study, we found intense and strong positivity for neuron-specific enolase in one case with abundant FlexnerWintersteiner rosettes.

Garrido et $a{ }^{35}$ reported that all differentiated RBs $(n=10)$ were positive for neuron-specific enolase, but only two of five poorly differentiated RBs were positive. This is consistent with other findings where the percentage of positive cases for neuron-specific enolase in poorly differentiated tumors

Table 5 Immunohistochemistry: synaptophysin: whole tissue sections and tissue microarray

\begin{tabular}{lll}
\cline { 1 - 2 } Synaptophysin & Whole tissue sections & Tissue microarray \\
\cline { 1 - 1 } Case number & & \\
\hline 1 & $75 \%-100 \%$ & $75 \%-100 \%$ \\
2 & $25 \%-75 \%$ & $<25 \%$ \\
3 & $75 \%-100 \%$ & $75 \%-100 \%$ \\
4 & $75 \%-100 \%$ & $25 \%-75 \%$ \\
5 & $75 \%-100 \%$ & $75 \%-100 \%$ \\
6 & $25 \%-75 \%$ & Missing cores \\
7 & $75 \%-100 \%$ & $75 \%-100 \%$ \\
8 & $75 \%-100 \%$ & $75 \%-100 \%$ \\
9 & $75 \%-100 \%$ & $75 \%-100 \%$ \\
10 & $75 \%-100 \%$ & $75 \%-100 \%$ \\
11 & $75 \%-100 \%$ & $75 \%-100 \%$ \\
12 & $75 \%-100 \%$ & $75 \%-100 \%$ \\
13 & $75 \%-100 \%$ & $75 \%-100 \%$ \\
14 & $75 \%-100 \%$ & $25 \%-75 \%$ \\
15 & $75 \%-100 \%$ & $75 \%-100 \%$ \\
16 & $75 \%-100 \%$ & $75 \%-100 \%$ \\
17 & $75 \%-100 \%$ & $75 \%-100 \%$ \\
18 & $75 \%-100 \%$ & $75 \%-100 \%$ \\
19 & $75 \%-100 \%$ & $75 \%-100 \%$ \\
20 & $75 \%-100 \%$ & $75 \%-100 \%$ \\
21 & $75 \%-100 \%$ & $75 \%-100 \%$ \\
22 & $75 \%-100 \%$ & $75 \%-100 \%$ \\
\hline & &
\end{tabular}

Note: Fraction of stained cells expressed in percentage of positive cells. 
Table 6 Immunohistochemistry: pRb: whole tissue sections and tissue microarray

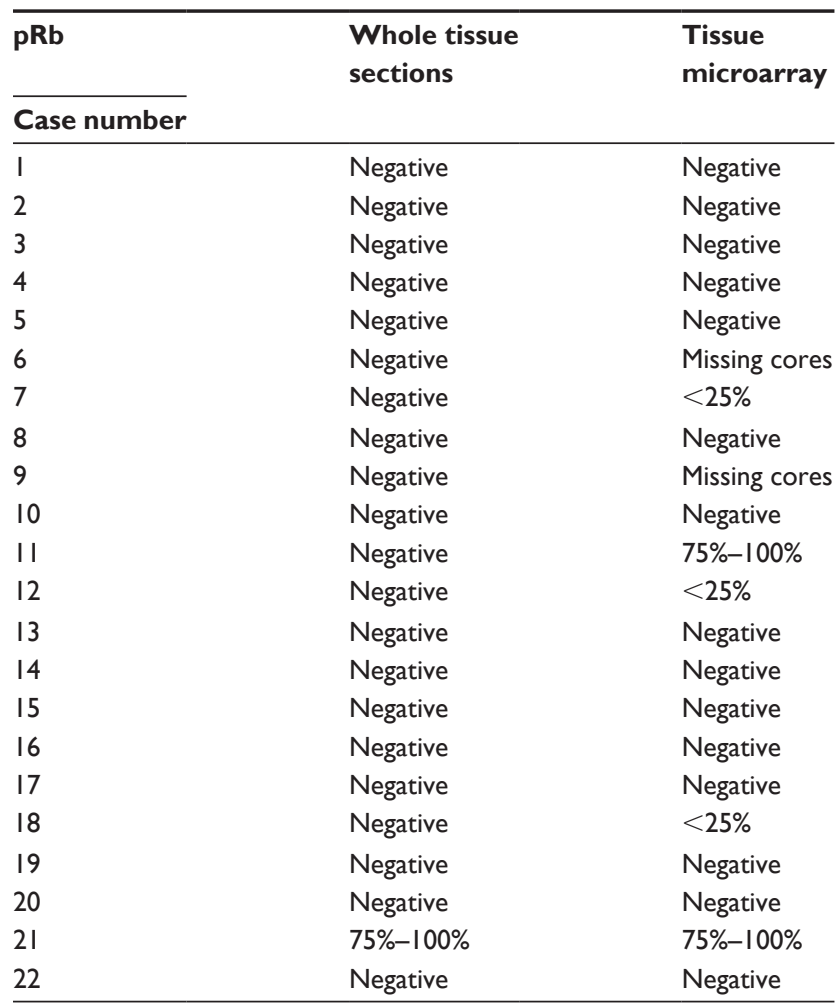

Note: Fraction of stained cells expressed in percentage of positive cells. Abbreviation: $\mathrm{pRb}$, retinoblastoma-associated protein.

was lower compared with well-differentiated RBs. ${ }^{31}$ In our study, we found intense staining for neuron-specific enolase in most of the 22 RBs that we studied. Furthermore, 21 of the 22 tumors were poorly differentiated. This is consistent with Sun et al who found that in 27 undifferentiated tumors, the cells were strongly positive for neuron-specific enolase. ${ }^{36} \mathrm{We}$ believe that the different results obtained by Molnar et al, ${ }^{34}$ Garrido et $a l,{ }^{35}$ and $\mathrm{He}$ et $\mathrm{al}^{31}$ compared to our results may be due to the use of a neuron-specific enolase ready-to-use monoclonal antibody that is more specific than the polyclonal antibodies used previously.

Yuge et al detected synaptophysin by immunohistochemistry only in the apical cytoplasm of cells forming rosettes, and no reactivity was observed in any of the undifferentiated tumors. ${ }^{29}$ Kivelä et al found that nine out of 27 poorly differentiated tumors were completely negative for synaptophysin, and $\mathrm{He}$ et al found similar results in 35 undifferentiated RBs. ${ }^{30,31}$ However, He et al also reported that synaptophysin was present in the rosettes of 41 differentiated tumors. In our series, synaptophysin was detected in all of the poorly differentiated RBs. We also found greater staining intensity for synaptophysin in the apical cytoplasm of FlexnerWintersteiner rosettes.
Yuge et al did not find $\mathrm{pRb}$ expression in a series of 34 $\mathrm{RBs}^{29}$ In contrast, Orjuela et al found nuclear $\mathrm{pRb}$ in 11 of $86 \mathrm{RBs}$, and 4 cases had diffuse staining in more than $80 \%$ of the tumor cells. ${ }^{37}$ They also concluded that tumors negative for $\mathrm{pRb}$ were those with extraocular extension. Low expression levels of $\mathrm{pRb}$ are also correlated with a worse prognosis in patients with prostate, breast, endometrial adenocarcinomas, and laryngeal carcinomas. ${ }^{38-41}$ Furthermore, transitional bladder cell carcinomas with decreased expression of $\mathrm{pRb}$ are more aggressive than tumors expressing $\mathrm{pRb}$ in most of the cells. ${ }^{42}$

Two of the RBs in our study were strongly positive for $\mathrm{pRb}$ and were classified as $\mathrm{pT} 4$, ie, tumors with invasion of the surgical margin and extraocular extension. Even though there was strong and diffuse expression of $\mathrm{pRb}$, this did not appear to be related to lower tumor aggressiveness. We believe that $\mathrm{pRb}$ could appear as a functionally inactive protein due to mutations that do not affect the expression. Alternatively, the RB protein could be present in a phosphorylated form that is not active, as documented in previous studies. $^{33,43,44}$

The concordance between whole tissue and tissue microarray immunohistochemical outcomes was greater than $76 \%$ for neuron-specific enolase, synaptophysin, and $\mathrm{pRb}$. This greatly exceeds the minimal acceptable level of $50 \%$. Thus, tissue microarray analysis of neuron-specific enolase and synaptophysin could be a valuable aid in RB diagnosis.

The main limitation of this study was the lack of follow-up and outcome data for the patients. Of the 21 patients, 20 were diagnosed and treated in Angola by local ophthalmologists; therefore, we were unable to access their medical records from Spain.

\section{Conclusion}

Retinoblastoma cells express the neural markers neuronspecific enolase and synaptophysin. Necrotic cells were also positive for neuron-specific enolase and synaptophysin. These results suggest that neuron-specific enolase and synaptophysin are useful markers for the diagnosis of RBs. This is especially so in those cases with extensive necrosis where no ocular structures are identifiable as is often the case in patients from developing countries. The extensive distribution and strong staining of $\mathrm{pRb}$ is not associated with a less aggressive behavior according to the pathologic classification of $\mathrm{RBs}^{23}$

To the best of our knowledge, this is the first tissue microarray study performed in RB samples. This technique is highly efficient, saving reagent costs and allowing all 
of the samples to be treated under the same conditions in a single experiment. Immunohistochemical analysis for neuron-specific enolase and synaptophysin could improve the diagnostic accuracy in RBs, which would be helpful in advanced and undifferentiated tumors.

\section{Acknowledgment}

The Spanish Agency for International Development Cooperation (Spain's Ministry of Foreign Affairs and Cooperation) contributed to the delivery of the specimens from Angola to Valladolid.

\section{Disclosure}

The authors alone are responsible for the content and writing of the article and report no conflicts of interest in this work.

\section{References}

1. National Cancer Institute [webpage on the Internet]. Age-Specific Rates and Counts for the Top 5 Cancer Sites by Single Year of Age at Diagnosis SEER Cancer Incidence 2007-2011. National Cancer Institute Surveillance, Epidemiology, and End Results Program. Available from: http://seer.cancer.gov/csr/1975_2011/browse_csr.php?sectionSEL=28 \&pageSEL=sect_28_table.13.html\#a. Accessed October 7, 2016.

2. Houston SK, Murray TG, Wolfe SQ, Fernandes CE. Current update on retinoblastoma. Int Ophthalmol Clin. 2011;51(1):77-91.

3. Kivelä T. The epidemiological challenge of the most frequent eye cancer: retinoblastoma, an issue of birth and death. $\mathrm{Br}$ J Ophthalmol. 2009;93(9):1129-1131.

4. Friend SH, Bernards R, Rogelj S, et al. A human DNA segment with properties of the gene that predisposes to retinoblastoma and osteosarcoma. Nature. 1986;323(6089):643-646.

5. Knudson AG Jr. Mutation and cancer: statistical study of retinoblastoma. Proc Natl Acad Sci U S A. 1971;68(4):820-823.

6. Bunin GR, Meadows AT, Emanuel BS, Buckley JD, Woods WG, Hammond GD. Pre- and postconception factors associated with sporadic heritable and nonheritable retinoblastoma. Cancer Res. 1989;49(20): 5730-5735.

7. Lee WH, Shew JY, Hong FD, et al. The retinoblastoma susceptibility gene encodes a nuclear phosphoprotein associated with DNA binding activity. Nature. 1987;329(6140):642-645.

8. Sachdeva UM, O'Brien JM. Understanding pRb: toward the necessary development of targeted treatments for retinoblastoma. $J$ Clin Invest. 2012;122(2):425-434.

9. Xu XL, Singh HP, Wang L, et al. Rb suppresses human cone-precursorderived retinoblastoma tumours. Nature. 2014;514(7522):385-388.

10. Yanoff M, Sassani JW. Retinoblastoma and pseudoglioma. In: Yanoff M, Sassani JW, editors. Ocular Pathology. St. Louis: Mosby Elsevier; 2009: 733-763.

11. McLean IW. Retinoblastomas, retinocytomas, and pseudoretinoblastomas. In: Spencer WH, editor. Ophthalmic Pathology: An Atlas and a Textbook. Philadelphia: W. B. Saunders Company; 1996: 1332-1438.

12. McLean IW, Burnier MN, Zimmerman LE, Jakobiec FA. Tumors of the retina. Atlas of Tumor Pathology. 3rd ed. Washington, DC: Armed Forces Institute of Pathology; 1994:97-154.

13. Hogan MJ, Zimmerman LE. Retina: neoplasms. In: Hogan MJ, Zimmerman LE, editors. Ophthalmic Pathology. An Atlas and Textbook. Philadelphia: W. B. Saunders Company; 1962:516-525.
14. Burnier MN, McLean IW, Zimmerman LE, Rosenberg SH. Retinoblastoma. The relationship of proliferating cells to blood vessels. Invest Ophthalmol Vis Sci. 1990;31(10):2037-2040.

15. The Human Protein Atlas [webpage on the Internet]. Methods: Immunohistochemistry. The Human Protein Atlas. Available from: http:// www.proteinatlas.org/learn/method/immunohistochemistry. Accessed October 7, 2016.

16. Coons AH, Creech HJ, Jones RN. Immunological properties of an antibody containing a fluorescent group. Exp Biol Med. 1941;47(2): 200-202.

17. Battifora $\mathrm{H}$. The multitumor (sausage) tissue block: novel method for immunohistochemical antibody testing. Lab Invest. 1986;55(2): 244-248.

18. Kononen J, Bubendorf L, Kallioniemi A, et al. Tissue microarrays for high-throughput molecular profiling of tumor specimens. Nat Med. 1998;4(7):844-847.

19. Ilyas M, Grabsch H, Ellis IO, et al; National Cancer Research Institute (UK) Biomarker and Imaging Clinical Studies Group. Guidelines and considerations for conducting experiments using tissue microarrays. Histopathology. 2013;62(2):827-839.

20. Camp RL, Charette LA, Rimm DL. Validation of tissue microarray technology in breast carcinoma. Lab Invest. 2000;80(12):1943-1949.

21. The Human Protein Atlas [webpage on the Internet]. Assays \& Annotation. The Human Protein Atlas. Available from: http://www.proteinatlas.org/ about/assays+annotation\#ih. Accessed October 7, 2016.

22. Sastre X, Chantada GL, Doz F, et al; International Retinoblastoma Staging Working Group. Proceedings of the consensus meetings from the International Retinoblastoma Staging Working Group on the pathology guidelines for the examination of enucleated eyes and evaluation of prognostic risk factors in retinoblastoma. Arch Pathol Lab Med. 2009;133(8):1199-1202.

23. Edge S, Byrd DR, Compton CC, Fritz AG, Greene FL, Trotti A, editors. AJCC Cancer Staging Manual. 7th ed. New York: SpringerVerlag; 2010.

24. Magramm I, Abramson DH, Ellsworth RM. Optic nerve involvement in retinoblastoma. Ophthalmology. 1989;96(2):217-222.

25. Eagle RC Jr. High-risk features and tumor differentiation in retinoblastoma: a retrospective histopathologic study. Arch Pathol Lab Med. 2009;133(8):1203-1209.

26. Sullivan EM, Wilson MW, Billups CA, et al. Pathologic risk-based adjuvant chemotherapy for unilateral retinoblastoma following enucleation. J Pediatr Hematol Oncol. 2014;36(6):e335-e340.

27. Dimaras H, Kimani K, Dimba EA, et al. Retinoblastoma. Lancet. 2012;379(9824):1436-1446.

28. Kyritsis AP, Tsokos M, Triche TJ, Chader GJ. Retinoblastoma - origin from a primitive neuroectodermal cell? Nature. 1984;307(5950): 471-473.

29. Yuge K, Nakajima M, Uemura Y, Miki H, Uyama M, Tsubura A. Immunohistochemical features of the human retina and retinoblastoma. Virchows Arch. 1995;426(6):571-575.

30. Kivelä T, Tarkkanen A, Virtanen I. Synaptophysin in the human retina and retinoblastoma. An immunohistochemical and Western blotting study. Invest Ophthalmol Vis Sci. 1989;30(2):212-219.

31. He W, Hashimoto H, Tsuneyoshi M, Enjoji M, Inomata H. A reassessment of histologic classification and an immunohistochemical study of 88 retinoblastomas. A special reference to the advent of bipolar-like cells. Cancer. 1992;70(12):2901-2908.

32. Xu KP, Liu SL, Ni C. Immunohistochemical evidence of neuronal and glial differentiation in retinoblastoma. Br J Ophthalmol. 1995;79(8): 771-776.

33. Cote RJ, Dunn MD, Chatterjee SJ, et al. Elevated and absent pRb expression is associated with bladder cancer progression and has cooperative effects with p53. Cancer Res. 1998;58(6):1090-1094.

34. Molnar ML, Stefansson K, Marton LS, Tripathi RS, Molnar GK. Immunohistochemistry of retinoblastomas in humans. Am J Ophthalmol. 1984;97(3):301-307. 
35. Garrido CM, Arra A. Studies of ocular retinoblastomas with immunoperoxidase techniques. Ophthalmologica. 1986;193(4):242-247.

36. Sun XL, Yokoyama T, Minoda K, Sakuma A. Immunohistochemical studies of retinoblastoma. Jpn J Ophthalmol. 1990;34(2):149-157.

37. Orjuela M, Orlow I, Dudas M, et al. Alterations of cell cycle regulators affecting the RB pathway in nonfamilial retinoblastoma. Hum Pathol. 2001;32(5):537-544.

38. Sharma A, Comstock CE, Knudsen ES, et al. Retinoblastoma tumor suppressor status is a critical determinant of therapeutic response in prostate cancer cells. Cancer Res. 2007;67(13):6192-6203.

39. Derenzini M, Montanaro L, Vici M, et al. Relationship between the RB1 mRNA level and the expression of phosphorylated RB protein in human breast cancers: their relevance in cell proliferation activity and patient clinical outcome. Histol Histopathol. 2007;22(5):505-513.

40. Semczuk A, Marzec B, Roessner A, Jakowicki JA, Wojcierowski J, Schneider-Stock R. Loss of heterozygosity of the retinoblastoma gene is correlated with the altered $\mathrm{pRb}$ expression in human endometrial cancer. Virchows Arch. 2002;441(6):577-583.
41. Pietruszewska W, Klatka J, Borzecki A, Rieske P. Loss of heterozygosity for $\mathrm{Rb}$ locus and $\mathrm{pRb}$ immunostaining in laryngeal cancer: a clinicopathologic, molecular and immunohistochemical study. Folia Histochem Cytobiol. 2008;46(4):479-485.

42. Cordon-Cardo C, Wartinger D, Petrylak D, et al. Altered expression of the retinoblastoma gene product: prognostic indicator in bladder cancer. J Natl Cancer Inst. 1992;84(16):1251-1256.

43. Rodríguez-Cruz M, Sanchez R, Arenas D, et al. pRb detection as a common event in human retinoblastomas: an immunohistochemical study. Acta Histochem. 2008;110(2):109-116.

44. Nork TM, Millecchia LL, Poulsen G. Immunolocalization of the retinoblastoma protein in the human eye and in retinoblastoma. Invest Ophthalmol Vis Sci. 1994;35(6):2682-2692.
Clinical Ophthalmology

\section{Publish your work in this journal}

Clinical Ophthalmology is an international, peer-reviewed journal covering all subspecialties within ophthalmology. Key topics include: Optometry; Visual science; Pharmacology and drug therapy in eye diseases; Basic Sciences; Primary and Secondary eye care; Patient Safety and Quality of Care Improvements. This journal is indexed on

Submit your manuscript here: http://www.dovepress.com/clinical-ophthalmology-journal

\section{Dovepress}

PubMed Central and CAS, and is the official journal of The Society of Clinical Ophthalmology (SCO). The manuscript management system is completely online and includes a very quick and fair peer-review system, which is all easy to use. Visit http://www.dovepress.com/ testimonials.php to read real quotes from published authors. 